UDC $515.2+563.3$

\title{
DETERMINATION OF LOAD DISTRIBUTION IN A GIVEN MEDIUM ACCORDING TO THE VALUES OF THE LOADS AT CERTAIN POINTS
}

\author{
O.V. Mostovenko, \\ Candidate of technical sciences, Associate professor \\ S.M. Kovalov, \\ Doctor of technical sciences, Professor \\ S.I. Botvinovska, \\ Doctor of technical sciences, Professor
Kyiv national university of construction and architecture, 31, Povitroflotskyi Ave., Kyiv,Ukraine, 03680

DOI: $10.32347 / 2410-2547.2021 .106 .167-175$

Taking into account force, temperature and other loads, the stress and strain state calculations methods of spatial structures involve determining the distribution of the loads in the threedimensional body of the structure [1,2].

In many cases the output data for this distribution can be the values of loadings in separate points of the structure. The problem of load distribution in the body of the structure can be solved by threedimensional discrete interpolation in four-dimensional space based on the method of finite differences, which has been widely used in solving various engineering problems in different fields. A discrete conception of the load distribution at points in the body or in the environment is also required for solving problems by the finite elements method [3-7].

From a geometrical point of view, the result of three-dimensional interpolation is a multivariate of the four-dimensional space [8], where the three dimensions are the coordinates of a three-dimensional body point, and the fourth is the loading at this point. Such interpolation provides for setting of the three coordinates of the point and determining the load at that point. The simplest three-dimensional grid in the three-dimensional space is the grid based on a single sided hypercube. The coordinates of the nodes of such a grid correspond to the numbering of nodes along the coordinate axes.

Discrete interpolation of points by the finite difference method is directly related to the numerical solutions of differential equations with given boundary conditions and also requires the setting of boundary conditions.

If we consider a three-dimensional grid included into a parallelepiped, the boundary conditions are divided into three types: 1) zero-dimensional (loads at points), where the three edges of the grid converge; 2) one-dimensional (loads at points of lines), where the four edges of the grid converge; 3 ) two-dimensional (loads at the points of faces), where the five edges of the grid converge. The zerodimensional conditions are boundary conditions for one-dimensional interpolation of the onedimensional conditions, which, in turn, are boundary conditions for two-dimensional conditions, and the two-dimensional conditions are boundary conditions for determining the load on the inner points of the grid.

If a load is specified only at certain points of boundary conditions, then the interpolation problem is divided into three stages: one-dimensional load interpolation onto the line nodes, two-dimensional load interpolation onto the surface nodes and three-dimensional load interpolation onto internal grid nodes.

The proposed method of discrete three-dimensional interpolation allows, according to the specified values of force, temperature or other loads at individual points of the three-dimensional body, to interpolate such loads on all nodes of a given regular three-dimensional grid with cubic cells.

As a result of interpolation, a discrete point framework of the multivariate is obtained, which is a geometric model of the distribution of physical characteristics in a given medium according to the values of these characteristics at individual points.

Key words: three-dimensional interpolation, method of finite differences, four-dimensional space, load, point, grid, boundary conditions.

Mostovenko O.V., Kovalov S.N., Botvinovska S.I. 


\section{Introduction}

The result of the three-dimensional interpolation, from a geometric point of view, is a multivariate of the four-dimensional space [8], where three dimensions are the coordinates of the point of a three-dimensional body, and the fourth is the load at this point. Such interpolation involves setting three coordinates of a point and determining the load at that point. The simplest three-dimensional grid in three-dimensional space is a grid based on a singleside hypercube. The coordinates of the nodes of such a grid correspond to the numeration of nodes along the coordinate axes.

Discrete interpolation of points by the method of finite difference is directly related to the numerical solutions of differential equations with given boundary conditions and also requires the setting of boundary conditions. If we consider a three-dimensional grid bounded by a parallelepiped (Fig. 1(a)), the boundary conditions are divided into three types:

- zero-dimensional (loads at points $A, C, H, F, V, X, Z, S$ ), where the three

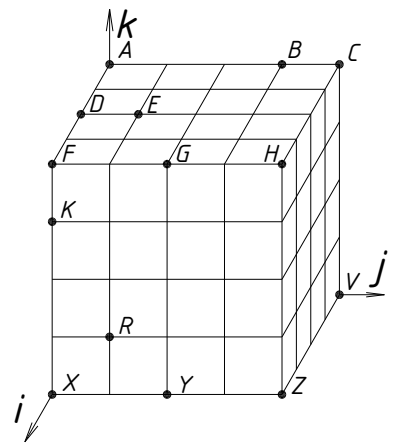

(a)

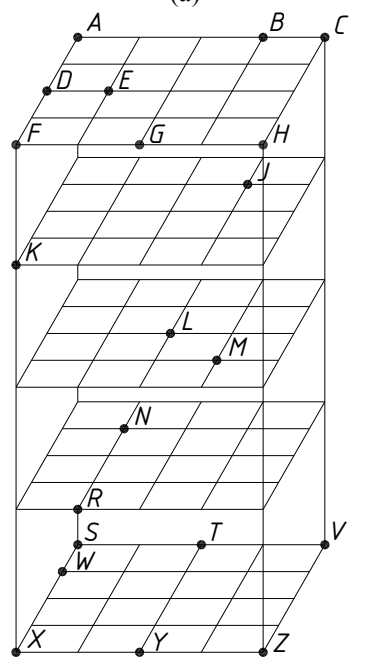

(б) edges of the grid converge;

- one-dimensional (loads at the points of the lines $A C, A F, F H, C H$, etc.), where the four edges of the grid converge;

- two-dimensional (loads at the points of the faces), where the five edges of the grid converge.

The zero-dimensional conditions are the boundary conditions for one-dimensional interpolation of one-dimensional conditions, which, in turn, are boundary conditions for two-dimensional conditions, and twodimensional conditions are boundary conditions for determining the load onto the inner points of the grid.

If a load is given only at certain points of boundary conditions, then the interpolation problem is divided into three stages:

1) one-dimensional load interpolation onto the line nodes;

2) two-dimensional load interpolation onto the surface nodes;

3) three-dimensional load interpolation onto the internal nodes of the grid.

The problem of discrete interpolation of the load $U_{i}$ on the grid with a uniform unit step in the first stage is solved on the basis of a system of finite and difference equations that connect the loads to adjacent points of the boundary edge of the grid:

Fig. 1 


$$
U_{i-1}-2 U_{i}+U_{i+1}+P_{i}=0,
$$

where $i$ - is the grid node number; $P$ - the value of the finite difference.

In the interval $A B$ (Fig. 2), the system (1) has $m-2$ equations with $m-n-2$ of unknown ordinates, where $n$ is the number of given intermediate nodes (point $C$ ). The number of equations of system (1) and the number of unknown coordinates $U_{\mathrm{i}}$ can be compared due to the unknown parameters of $P_{i}$.

It is known $[9,10]$ that if the graph of the distribution of the parameter $P_{i}$ has a overfall, or individual values of $P_{i}$ are not

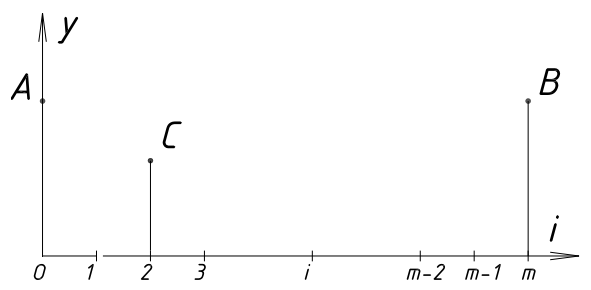

Fig. 2 functionally related to the adjacent values of $P_{i}-1$ and $P_{i}+1$, then the Discretely Presented Curve (DPC) in such places has a break. If the graph of the distribution of the parameter $P_{i}$ has a break, then the DPC consists of smooth joint (in the discrete sense) curves. Therefore, it is proposed to form the distribution of the parameter $P_{i}$ on the principle of the DPC formation, introducing additional parameters $Q_{i}$ :

$$
P_{i-1}-2 P_{i}+P_{i+1}+Q_{i}=0 .
$$

In fig. 3 three graphs are shown where the graph of the change of the parameter $Q$ at the point $M^{\prime \prime}$ has a difference, the graph of the change of the parameter $P$ at the point $M^{\prime}$ has a break, and the graph of the change of the coordinate $U$ at the point $M$ is a smooth junction of the two DPCs.

When solving discrete interpolation problems the parametric analysis of the initial conditions becomes important, as the number of unknowns in systems (1) and (2) has to be equal to the number of equations. The tables show the correspondence of the number of equations (1) and (2) to the number of the unknown $U_{i}, P_{i}$ and $Q_{i}$ with the arbitrary number $0 \leq n \leq m-2$ of the given intermediate nodes in the interval that has $(m-1)$ steps.

Table

\begin{tabular}{|c|c|c|c|c|c|}
\hline$n$ & $\begin{array}{c}\text { Number of } \\
\text { equations (1) }\end{array}$ & $\begin{array}{c}\text { Number of } \\
\text { equations (2) }\end{array}$ & $\begin{array}{l}\text { Number of } \\
\text { unknown } y_{i}\end{array}$ & $\begin{array}{l}\text { Number of } \\
\text { unknown } P_{i}\end{array}$ & $\begin{array}{l}\text { Number of } \\
\text { unknown } Q_{i}\end{array}$ \\
\hline 0 & $m-1\left(P_{i}=0\right)$ & 0 & $m-1$ & 0 & 0 \\
\hline 1 & $m-1\left(P_{i}=P\right)$ & 0 & $m-3$ & $m-1$ & 0 \\
\hline 2 & $m-1$ & $m-3$ & $m-4$ & $m-1$ & 1 \\
\hline 3 & $m-1$ & $m-3$ & $m-5$ & $m-1$ & 2 \\
\hline 4 & $m-1$ & $m-3$ & $\ldots$ & $\ldots$ & $\ldots$ \\
\hline$\ldots$ & $\ldots$ & $\ldots$ & 1 & $m-1$ & $m-2$ \\
\hline$m-2$ & $m-1$ & $m-3$ & & & \\
\hline
\end{tabular}

The first row of the table shows the case when no intermediate nodes are specified. Then the equation (1) takes the form: 


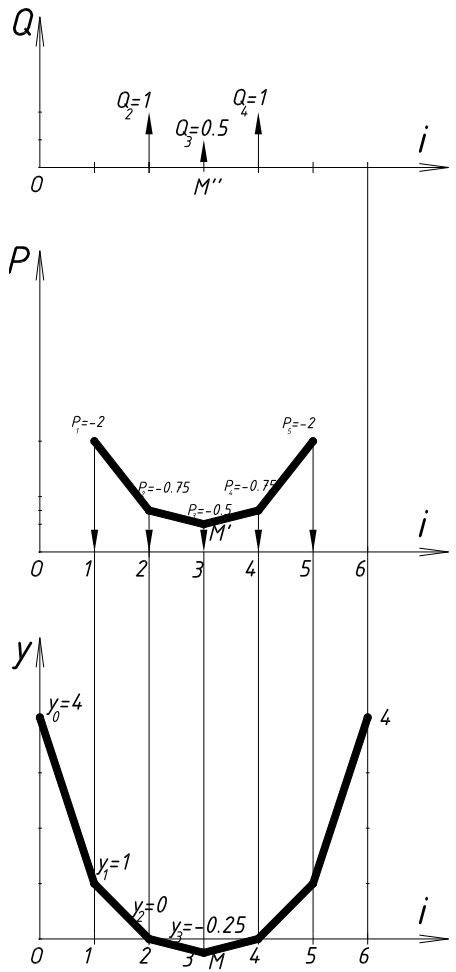

Fig. 3

$$
U_{i-1}-2 U_{i}+U_{i+1}=0
$$

and the DPC is a uniform series of points on the line connecting the endpoints $A$ and $B$.

The second row of the table shows the case when one intermediate point is given, and the unknown parameter $P$ is the same in all equations (1):

$$
U_{i-1}-2 U_{i}+U_{i+1}+P=0 .
$$

The third row of the table $(\mathrm{n}=2)$ shows that for two given intermediate points, the equation (2) takes the form:

$$
P_{i-1}-2 P_{i}+P_{i+1}=0 \text {. }
$$

The numbers of the equations (1) and (2) are shown in the last row of the table, if one node's coordinate of the DPC is unknown, and all others are given.

This principle of one-dimensional interpolation can be used for the problem solving of the two-dimensional and multidimensional interpolation of points on a uniform grid.

In the second stage, the twodimensional interpolation completes the difference equations (1) and (2), and they, respectively, take the form:

$$
\begin{aligned}
& U_{i-1, j}+U_{i+1, j}+U_{i, j-1}+U_{i, j+1}-4 U_{i, j}+P_{i, j}=0, \\
& P_{i-1, j}+P_{i+1, j}+P_{i, j-1}+P_{i, j+1}-4 P_{i, j}+Q_{i, j}=0,
\end{aligned}
$$

where the results of the one-dimensional interpolation of the contour DPC are accepted as boundary conditions for two-dimensional interpolation

The systems of equations (3) and (4) are formed for all the internal nodes of the grid. For a grid having $m \times n$ cells, we have $(m-1)(n-1)$ of the equations (3), which have $(m-2)(n-2)-l$ of the variable parameters $U_{i, j}$, where $l-$ is the number of given parameters $U_{i, j}$ of the internal nodes. The equations of system (4) are also compiled for all the internal nodes of the grid, and $P_{i, 0}=P_{i, m}=P_{0, j}=P_{n, j}=0$ in order to include the parameters $P_{1,1} ; P_{m-1,1} ; P_{1, n-1}$ i $P_{m-1, n-1}$ to this system.

Then the system (4) calculates the equation $(m-2)(n-2)$ and has $(m-2)(n-$ 2 ) of the virables of $P_{i, j}$ parameters and $(m-2)(n-2)$ of the variables of $Q_{i, j}$ parameter. Together, the systems (3) and (4) have $2(m-2)(n-2)$ equations and have $3(m-2)(n-2)-l$ of variables. In order for the number of variables to be equal to the number of equations, the system (4) requires the number $(m-2)(n-$ 2) of $Q_{i, j}$ variables to be reduced to 1 . This can be done by adding to the systems (3) and (4) the equations $(m-2)(n-2)-l$ of the type $Q_{i-1, j}=Q_{i, j}$, or $Q_{i, j}=Q_{i, j}$. 
In the third stage, three-dimensional interpolation is performed, the boundary conditions for which are the two-dimensional grids obtained in the second stage. For all the internal nodes of the three-dimensional grid the finitedifference equations are formed:

$$
\begin{aligned}
& U_{i-1, j, k}+U_{i+1, j, k}+U_{i, j-1, k}+U_{i, j+1, k}+U_{i, j, k-1}+U_{i, j, k+1}-6 U_{i, j, k}+P_{i, j, k}=0, \\
& P_{i-1, j, k}+P_{i+1, j, k}+P_{i, j-1, k}+P_{i, j+1, k}+P_{i, j, k-1}+P_{i, j, k+1}-6 P_{i, j, k}+Q_{i, j, k}=0 .
\end{aligned}
$$

The number of the variables $Q_{i, j, k}$ must be equal to the number of specified parameters $U_{i, j, k}$ of the internal nodes of the three-dimensional grid.

Example (Fig. 1).

It is given the uniform three-dimensional grid in a limited space $0 \leq i \leq 4 ; 0 \leq j \leq 4 ; 0 \leq k \leq 4$.

We are given the coordinates $i, j, k, U$ of the nodes $A, B, \ldots, Z: A(0 ; 0 ; 4$; 8.94), $B(0 ; 3 ; 4 ; 9.43), C(0 ; 4 ; 4 ; 9.8), D(2 ; 0 ; 4 ; 7.21), E(2 ; 1 ; 4 ; 7.28), F(4 ; 0$; 4 ; 5.66), G(4; $2 ; 4 ; 6), H(4 ; 4 ; 4 ; 6.93), J(1 ; 3 ; 3 ; 8.19), K(4 ; 0 ; 3 ; 5), L(2 ; 2 ; 2$; 6.63), $M(3 ; 3 ; 2 ; 6.16), N(1 ; 1 ; 1 ; 7.14), R(4 ; 1 ; 1 ; 4.24), S(0 ; 0 ; 0 ; 8), T(0 ; 2 ; 0$; 8.25), $V(0 ; 4 ; 0 ; 8.94), W(1 ; 0 ; 0 ; 7), X(4 ; 0 ; 0 ; 4), Y(4 ; 2 ; 0 ; 4.47), Z(4 ; 4 ; 0$; 5.66). We need to determine the value of the parameter $U_{i, j, k}$ in the other nodes of the grid.

In the first stage, the interpolation of onedimensional elements $A C, A F, F H, C H, S V, S X, V Z$, $X Z, F X, A S, C V, H Z$ according to formulas (1) and (2) is performed.

In the second stage, according to the known values of the parameter $U_{i, j, k}$ of the vertices of onedimensional elements the values of the parameter $U_{i, j, k}$ are defined for the nodes of two-dimensional boundaries $A C H F, X S V Z, A S X F, A C V S, H C V Z$, $F H Z X$ when compiling and solving systems of equations (3) and (4).

In the third stage, according to the known values of the parameters $U_{i, j, k}$ of the points of twodimensional elements of the boundaries the values of the parameter $U_{i, j, k}$ are defined for internal nodes of the given three-dimensional grid when solving the system (5).

According to the results of calculations in Fig. 4, a discrete framework of the hypersurface $U_{i, j, k}=f(i, j, k)$ is constructed in layers, which illustrates the load distribution in a given volume.

\section{Conclusions}

The proposed method of discrete threedimensional interpolation allows, according to the specified values of force, temperature or other loads at individual points of the three-dimensional body,

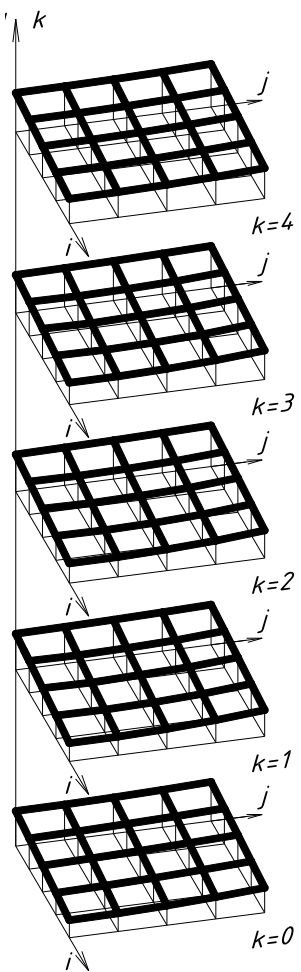

Fig. 4 
to interpolate these loads on all nodes of a given regular three-dimensional grid with cubic cells. As a result of the interpolation, a discrete point framework of the multivariate is obtained, which is a geometric model of the distribution of physical characteristics in a given medium according to the values of these characteristics at individual points.

\section{REFERENCES}

1. Bazhenov V.A. Vyznachennia oblasti vidmovy naftovoho rezervuara $\mathrm{z}$ nedoskonalostiamy stinky pry kombinovanomu navantazhenni (Definition of the failure region of the oil tank with wall imperfections in combined loading) / V.A. Bazhenov, O.O. Lukianchenko, O.V. Kostina // Strength of Materials and Theory of Structures. 2018. № 100-2018. - Vip.100. - P. 27 - 39.

2. Solodei I.I. Vyznachennia navantazhen vid masyvu gruntovykh sypuchykh porid pry proektuvanni pidzemnykh sporud (Determination of loads from array of runningsoil when designing underground structures) / I.I. Solodei, H.A. Zatiliuk. // Opir materialiv i teoriia sporud. - 2016. - №97. - P. 145-154.

3. Bazhenov V.A. Osobennosty yspolzovaniya momentnoy skhemy konechnykh elementov (MSKE) pry nelineynykh raschetakh obolochek i plastyn (Peculiarities of using the finite element moment scheme (FEMS) in nonlinear calculations of shells and plates) / V.A. Bazhenov, O.S. Saharov, O.I. Gulyar, C.O. Piskunov, Yu.V. Maksimyuk // Opir materialiv i teoriya sporud. - 2017. - Vip.92. - P. 3-16.

4. Bazhenov V.A. Napivanalitychnyi metod skinchennykh elementiv u zadachakh ruinuvannia zvychainykh tverdykh til (Semi-analytic method of finite elements in problems of destruction of ordinary solids) / [Bazhenov V.A., Hulyar O.I., Pyskunov S.O., Sakharov O.S.] - K., KNUBA, 2005. $-298 \mathrm{p}$.

5. Bazhenov V.A. Chyselne modeliuvannia ruinuvannia zalizobetonnykh konstruktsii metodom skinchennykh elementiv (Numerical modeling of the destruction of reinforced concrete structures using the finite element method) / [Bazhenov V.A., Gulyar A.I., Kozak A.L., Rutkovskiy V.A., Sakharov A.S.] - K., Naukova dumka, 1996. - 360 p.

6. Hlushchenkov V.A. Chyselne doslidzhennya protsesiv vysokoshvydkisnoho deformuvannya na osnovi metodu skinchennykh elementiv (Numerical study of high-speed deformation processes based on finite element method) / [Hlushchenkov V.A. etc.] // Mashynovedenye. 1986. №4. P.146-151.

7. Maksimyuk Yu.V. Kintsevyi element zahalnoho typu dlia rozviazannia osesymetrychnoi zadachi pro nestatsionarnu teploprovidnist (A finite element of general type for the solution of an axisymmetric problem of non-stationary heat conductivity) / Yu.V. Maksimyuk // Opir materialiv i teoriya sporud: nauk.-tehn. zbirnik / Vidp. red. V.A.Bazhenov. - K.:KNUBA, Vip.96, 2015. P. 148-157.

8. Pugachev E.V. Dyskretna interpoliatsiia dyskretno predstavlenykh hiperpoverkhon $\mathrm{v}$ chotyryvymirnomu evklidovomu prostori (Discrete interpolation of discretely represented hypersurfaces in four-dimensional Euclidean space) /E.V. Pugachev / Interdepartmental Scientific and Tech. collection "Applied Geometry and Eng. graphics ". Issue 67. Editor-inChief V.Ye. Mikhailenko.- K .: KNUBA, 2000.- P. 96-99.

9. Kovalov S.M. Statychna ta heometrychna interpretatsiia trytochkovykh riznytsevykh operatoriv dlia odnovymirnoi priamoi ta zvorotnoi interpoliatsii (Static and geometric interpretation of three-point difference operators for one-dimensional forward and backward interpolation) / S.M. Kovalov, V.O. Vyazankin, S.I. Pustyulga // Proceedings of the Tavriya State Agrotechnical Academy. - Melitopol, 2004. - Issue. 4, v. 28. - P. 21-25.

10. Zolotova A.V. Odnovymirna dyskretna interpoliatsiia tochok na ploshchyni (One-dimensional discrete interpolation of points on the plane) / A.V. Zolotova // Scientific notes. Interuniversity collection (in the field of "Engineering Mechanics"). Vip. 22, part 2. - Lutsk, 2008. - P. 125-130. 


\section{Мостовенко О.В., Ковальов С.М., Ботвіновська С.І. \\ ВИЗНАЧЕННЯ РОЗПОДІЛУ НАВАНТАЖЕНЬ У ЗАДАНОМУ СЕРЕДОВИЩІ ЗА ЗНАЧЕННЯМИ ТАКИХ НАВАНТАЖЕНЬ В ОКРЕМИХ ТОЧКАХ}

Методи розрахунків напружено-деформованого стану просторових конструкцій 3 урахуванням силових, температурних та інших навантажень передбачають визначення розподілу таких навантажень у тривимірному тілі конструкції $[1,2]$.

Вихідними даними для такого розподілу у багатьох випадках можуть бути значення навантажень в окремих точках тіла конструкції. Задачу розподілу навантажень у тілі конструкції можна розв'язати за допомогою тривимірної дискретної інтерполяції у чотиривимірному просторі на основі методу скінчених різниць, який набув широкого використання при вирішенні різноманітних інженерних задач у різних галузях. Дискретне уявлення розподілу навантаження у точках тіла або середовища потрібно також для розв'язання задач методом скінчених елементів [3-7].

Результат тривимірної інтерполяції, 3 геометричної точки зору, $є$ багатовидом чотиривимірного простору [8], де три виміри $є$ координатами точки тривимірного тіла, а четвертий - навантаження у цій точці. Така інтерполяція передбачає задання трьох координат точки і визначення навантаження у цій точці. Найпростішою тривимірною сіткою у тривимірному просторі $\epsilon$ сітка на основі гіперкуба з одиничною стороною. Координати вузлів такої сітки відповідають нумерації вузлів уздовж координатних осей.

Дискретна інтерполяція точок методом скінчених різниць має безпосередній зв'язок 3 чисельним розв'язанням диференціальних рівнянь з заданими крайовими умовами і так само потребує задання крайових умов.

Якщо розглядати тривимірну сітку, обмежену паралелепіпедом, то крайові умови поділяються на три типи: 1)нульвимірні (навантаження в точках), де сходяться по три ребра сітки; 2) одновимірні (навантаження в точках ліній), де сходяться по чотири ребра сітки; 3 ) двовимірні (навантаження в точках граней), де сходяться по п'ять ребер сітки. Нульвимірні умови $\epsilon$ крайовими для одновимірної інтерполяції одновимірних умов, які в свою чергу $\epsilon$ крайовими умовами для двовимірних умов, а двовимірні умови є крайовими умовами для визначення навантаження на внутрішні точки сітки.

Якщо задано навантаження тільки в окремих точках крайових умов, то задача інтерполяції поділяється на три етапи: одновимірна інтерполяція навантаження на вузли ліній, двовимірна інтерполяція навантаження на вузли поверхонь та тривимірна інтерполяція навантаження на внутрішні вузли сітки.

Запропонований спосіб дискретної тривимірної інтерполяції дозволяє за заданими значеннями силових, температурних або інших навантажень в окремих точках тривимірного тіла проінтерполювати такі навантаження на всі вузли заданої регулярної тривимірної сітки 3 кубічними клітинами. У результаті інтерполяції отримується дискретний точковий каркас багатовиду, який є геометричною моделлю розподілу фізичних характеристик у заданому середовищі за значеннями таких характеристик в окремих точках.

Ключові слова: тривимірна інтерполяція, метод скінчених різниць, чотиривимірний простір, навантаження, точка, сітка, крайові умови.

\section{Мостовенко А.В., Ковалев С.Н., Ботвиновская С.И. \\ ОПРЕДЕЛЕНИЕ РАСПРЕДЕЛЕНИЯ НАГРУЗКИ В ЗАДАННОЙ СРЕДЕ ПО ЗНАЧЕНИЯМ ТАКИХ НАГРУЗОК В ОТДЕЛЬНЫХ ТОЧКАХ}

Методы расчета напряженно-деформированного состояния пространственных конструкций с учетом силовых, температурных и других нагрузок предусматривают определение распределения таких нагрузок в трехмерном теле конструкции $[1,2]$.

Исходными данными для такого распределения во многих случаях могут быть значения нагрузок в отдельных точках тела конструкции. Задачу распределения нагрузок в теле конструкции можно решить с помощью трехмерной дискретной интерполяции в четырехмерном пространстве на основе метода конечных разностей, который получил широкое использование при решении различных инженерных задач в различных областях. Дискретное представление распределения нагрузки в точках тела или среды нужно также для решения задач методом конечных элементов [3-7].

Результат трехмерной интерполяции, с геометрической точки зрения, является многообразием четырехмерного пространства [8], где три измерения являются координатами точки трехмерного тела, а четвертым - нагрузка в этой точке. Такая интерполяция предусматривает задания трех координат точки и определения нагрузки в этой точке. Простой трехмерной сеткой в трехмерном пространстве есть сетка на основе 
гиперкуба с единичной стороной. Координаты узлов такой сетки соответствуют нумерации узлов вдоль координатных осей.

Дискретная интерполяция точек методом конечных разностей имеет непосредственую связь с численным решением дифференциальных уравнений с заданными краевыми условиями и так же требует задания краевых условий.

Если рассматривать трехмерную сетку, ограниченную параллелепипедом, то краевые условия делятся на три типа: 1) нульмерные (нагрузка в точках), где сходятся по три ребра сетки; 2) одномерные (нагрузка в точках линий), где сходятся по четыре ребра сетки 3) двухмерные (нагрузка в точках граней), где сходятся по пять ребер сетки. Нульмерные условия являются краевыми для одномерной интерполяции одномерных условий, которые в свою очередь являются краевыми условиями для двумерных условий, а двумерные условия являются краевыми условиями для определения нагрузки на внутренние точки сетки.

Если задана нагрузка только в отдельных точках краевых условий, то задача интерполяции делится на три этапа: одномерная интерполяция нагрузки на узлы линий, двумерная интерполяция нагрузки на узлы поверхностей и трехмерная интерполяция нагрузки на внутренние узлы сетки.

Предложенный способ дискретной трехмерной интерполяции позволяет по заданным значениям силовых, температурных или других нагрузок в отдельных точках трехмерного тела проинтерполировать такие нагрузки на все узлы заданной регулярной трехмерной сетки с кубическими клетками. В результате интерполяции получается дискретный точечный каркас гиперповерхности, который является геометрической моделью распределения физических характеристик в заданной среде по значениям таких характеристик в отдельных точках.

Ключевые слова: трехмерная интерполяция, метод конечных разностей, четырехмерное пространство, нагрузка, точка, сетка, краевые условия.

\section{УДК $515.2+563.3$}

Мостовенко О.В., Ковальов С.М., Ботвіновська С.I. Визначення розподілу навантажень у заданому середовищі за значеннями таких навантажень в окремих точках // Опір матеріалів і теорія споруд: наук.-тех. збірн. - Київ: КНУБА, 2021. - Вип. 106. - С. 167-175.Engl.

Методи розрахунків напружено-деформованого стану просторових конструкцій $з$ урахуванням силових, температурних та інших навантажень передбачають визначення розподілу таких навантажень у тривимірному тілі конструкиї.

Табл. 1. Іл. 4. Бібліогр. 10 назв.

UDC $515.2+563.3$

Mostovenko O.V., Kovalov S.N., Botvinovska S.I. Determination of load distribution in a given medium according to the values of the loads at certain points // Strength of Materials and Theory of Structures: Scientific and technical collected articles. - Kyiv: KNUBA, 2021. - Issue 106. - P. 167-175.

Taking into account force, temperature and other loads, the stress and strain state calculations methods of spatial structures involve determining the distribution of the loads in the three-dimensional body of the structure.

Tabl. 1. Fig. 4. Ref. 10.

УДК $515.2+563$.

Мостовенко О.В., Ковальов С.М., Ботвіновська С.I.

Определение распределения нагрузки в заданной среде по значениям таких нагрузок в отдельных точках// Опір матеріалів і теорія споруд: наук.-тех. збірн. - Київ: КНУБА, 2021. - Вып. 106. - С. 167-175.-Engl.

Методы расчета напряженно-деформированного состояния пространственных конструкиий с учетом силовых, температурных и других нагрузок предусматривают определение распределения таких нагрузок в трехмерном теле конструкиии.

Табл. 1. Рис. 4. Библиогр. 10 назв. 
Автор (науковий ступінь, вчене звання, посада): кандидат технічних наук, доцент, докторант кафедри нарисної геометрії та інженерної графіки КНУБА МОСТОВЕНКО Олександр Володимирович.

Адреса: 03680 Україна, м. Київ, Повітрофлотський просп., 31, КНУБА, кафедра нарисної геометрії та інженерної графіки, Мостовенку Олександру Володимировичу.

Робочий тел.: +38(044) 241-55-47

Мобільний тел.: +38(050) 609-90-97

E-mail: a.mostovenko25@gmail.com

ORCID ID: https://orcid.org/0000-0002-3423-4126

Автор (науковий ступінь, вчене звання, посада): доктор технічних наук, професор, професор кафедри нарисної геометрії та інженерної графіки КНУБА КОВАЛЬОВ Сергій Миколайович.

Адреса: 03680 Україна, м. Київ, Повітрофлотський просп., 31, КНУБА, кафедра нарисної геометрії та інженерної графіки, Ковальову Сергію Миколайовичу.

Робочий тел.: +38(044) 241-55-47

Мобільний тел.: +38(066) 103-64-35

E-mail: snkovalov41@gmail.com

ORCID ID: https://orcid.org/0000-0002-7713-1768

Автор (науковий ступінь, вчене звання, посада): доктор технічних наук, професор, завідувачка кафедри нарисної геометрії та інженерної графіки КНУБА БОТВІНОВСЬКА Світлана Іванівна.

Адреса: 03680 Україна, м. Київ, Повітрофлотський просп., 31, КНУБА, кафедра нарисної геометрії та інженерної графіки, Ботвіновській Світлані Іванівні.

Робочий тел.: +38(044) 241-55-47

Мобільний тел.: +38(066) 213-02-58

E-mail: botvinovska@ua.fm

ORCID ID: https://orcid.org/0000-0002-1832-1342 